\title{
EMPRESA AGRÁRIA E ESTABELECIMENTO AGRÁRIO
}

\author{
Fábio Maria De-Mattia
}

Professor Titular do Departamento de Direito Civil da

Faculdade de Direito da Universidade de São Paulo

\section{Resumo:}

Empresa e estabelecimento constituem dois institutos importantes no desenvolvimento da atividade agrária.

A primeira consubstancia o elemento subjetivo - sujeito de direito

e a segunda o elemento objetivo. Este se constitui dos bens, direitos, créditos, garantias, etc.

Os dois institutos são examinados em seus vários aspectos com os subsídios da teoria dominante.

\begin{abstract}
:
Enterprise and establishment are two important concepts to the development of agrarian activity.

The former is the subjective element - subject of rights and the latter is the objective element, consisting of goods, rights, credits, warranties, etc.

Both of the concepts are analyzed here in several aspects with the support of the predominant theory.
\end{abstract}

\section{Capítulo I}

\section{A EMPRESA AGRÁRIA}

\section{Sumário}

1 A empresa agrária empresário agrário.

2 Diferença entre empresa agrária e sociedade comercial, tendo por escopo atividade agrária.

3 Obrigações do empresário agrário.

4 As empresas coletivas agrárias.

5 As associações de empresas agrárias.

6 O pequeno empresário agrário.

7 - Contrato agrário e empresa agrária.

8 - A noção de unidade produtiva.

9 - Empresa agrária no Direito brasileiro. 
1 - A Empresa agrária - empresário agrário

Ettore Casadei inicia sua exposição sobre a matéria com uma reflexão válida para o Direito Agrário brasileiro, assevera que a disciplina da empresa agrária adequa-se ao paradigma da empresa, mas é deficiente, escassa de conteúdo, pobre de normas particulares de onde se iniciam os desvios dos princípios comuns que proporcionam relevo ou vida à autonomia do instituto.

A conseqüência da configuração do instituto empresa agrária encontrase no entendimento de que as obrigações estatuídas pela norma legal recaem sobre o empresário e não sobre o proprietário da terra. Este é um princípio basilar da disciplina da empresa, a qual se dirige aos seus titulares e não aos proprietários dos bens agregados na empresa. ${ }^{1}$

Admitida a noção de empresário centrada na atividade econômica exercida, profissionalmente, com o escopo de produção ou troca de bens ou de serviços, considerado o interesse da empresa revelado através de dois tipos a empresa agrária e a empresa comercial em sentido lato o aparecimento de outros esquemas não-qualificáveis como integrando os dois tipos referidos, mas, caracterizadas mais propriamente como pessoas jurídicas denominadas civis, a empresa agrária destas se distinguiria tão-somente pelo objeto e não pela estrutura, o que the negaria qualquer autonomia, classificando-a como uma subespécie de uma categoria mais ampla de empresa civil.

Ettore Casadei, numa lição aplicável à empresa agrária como regulada no Direito brasileiro, encontrou como justificação mais verdadeira para a disciplina das empresas agrárias, como reguladas no Código Civil italiano, a tarefa de conter o impulso expansionista da comercialidade. Referido ordenamento não se inspirou num esquema simétrico, mas seguiu nas conseqüências o método realístico da economia, quando subtraiu a atividade agrária da aplicação de regras que constituem a textura dos institutos característicos do Direito Comercial e quando atribuiu uma relevância, ainda que negativa, à empresa agrária.

O estudo comparativo da disciplina dos dois tipos de empresa conclui que o empresário agrário não está sujeito, em regra, à luz do Código Civil italiano: 1. à inscrição no registro das empresas; 2. não são previstas formas de publicidade para a procuração do representante, do preposto no exercício da empresa; 3 . o empresário

1 Casadei, Ettore, Diritto Agrario, 1975, apostila utilizada pelos alunos da Faculdade de Jurisprudência da Universidade de Bologna e Modena, p. 27. 
agrícola não é obrigado a manter e conservar livros contábeis; 4 . não se lhes aplicam as regras pertinentes aos institutos da falência e concordata preventiva; 5. não estão previstas limitaçð̃es particulares quanto à sua capacidade.

Estes aspectos constituem traços diferenciadores das empresas comerciais e industriais em comparação com a empresa agrária.

A publicidade, a manutenção de livros contábeis, a falência ou o favor legis da concordata preventiva, são garantias destinadas a facilitar o fluxo de crédito, a estabelecer rapidamente relaç̃̃es negociais, a simplificar as contratações, como ocorre nas empresas comerciais, que têm por objeto de atividades bens e serviços, e nas empresas industriais, que adquirem matérias-primas para pô-las à disposição do público depois de havê-las transformado. ${ }^{2}$

Giuseppe Ragusa Maggiore sustenta que o Direito Agrário e o Direito Comercial não se encontram em dois planos distintos e não-comunicantes, mas constituem ambos o Direito da Empresa em uma particular manifestação da atividade econômica. Pode-se recorrer, portanto, a um dos ramos do Direito para interpretar espécies que pareçam obscuras, isto porque, os dois ramos constituem um sistema unitário disponível para regular a atividade produtiva do homem. ${ }^{3}$

A distinção entre empresa agrária e empresa comercial se depara com a diferença de atividade.

O agricultor não é um intermediário na troca dos bens, mas é o produtor que coloca em circulação o bem novo produzido pela terra ou não: $o$ ato de alienação do agricultor está em uma das extremidades daquela cadeia de passagens, através das quais os bens vão de quem os produz a quem os consuma. Em verdade a atividade negocial do agricultor desenvolve-se na prevalência da alienação. $O$ agricultor, normalmente, adquire no mercado somente em parte os bens auxiliares, sendo certo que o próprio fundo, herdade, produz muitos deles: sementes, estrume, palha, feno e até animais de trabalho. ${ }^{4}$

Um argumento que poderia ser contraposto ao acima asseverado fundamenta-se no fato de o agricultor necessitar de uma aquisição inicial, e porque inicial, enquadra-se na atividade preparatória e organizadora do estabelecimento. A

2 Id., ibid. p. 28.

3 Maggiore, Giuseppe Ragusa, L'impresa agricola e suoi aspetti di Diritto commerciale e falimentare, Napoli: Morano Editore, , p. 31. 1964

4 Casadei, Ettore, ob. cit. p. 29. 
agricultura necessita do apoio de meios químicos e mecânicos, de produtos de indústrias especializadas e de outras empresas agrárias, daí o recurso a atos de aquisição ser uma necessidade também para o empresário agrário.

$\mathrm{O}$ agricultor não se abastece no mercado livre, por um complexo de motivos, segue caminhos já predispostos: os instrumentos, as máquinas, os adubos químicos, os produtos anticritogâmicos, as sementes, etc. lhes são fornecidos a crédito ou através de pagamento à vista, pelas associaç̃̃es de agricultores, constituídas com o fim de abastecer nas melhores condiçøes os sócios ou associados com os bens necessários aos seus estabelecimentos. ${ }^{5}$

O empresário agrário apresenta-se isolado das atividades mercantis, daí se justificar a exigência de menos formalidades, tais como as já acenadas de publicidade da empresa, existência de procuração, conservação e manutenção de livros habituais no Direito Comercial. Com efeito, a atividade agrária se desenvolve, prevalecentemente, no campo técnico e não no negocial, enquanto a empresa agrária, por causa de sua consistência fundiária, oferece garantias mais sólidas e infalíveis. ${ }^{6}$

Quando o objeto da empresa é a atividade de cultivo, de criação de animais ou de silvicultura, a existência ou a falta da personalidade jurídica não tem relevo.

Igualmente, pouco importa para a natureza da atividade que a empresa de cultivo, por exemplo, com mão-de-obra assalariada, seja gerida por uma pessoa fisica, por uma coletividade de pessoas fisicas ou por uma pessoa jurídica. ${ }^{7}$

O exercício da empresa agrária não requer, necessariamente, que o empresário seja o proprietário do fundo, basta um poder de fato, cujo conteúdo é uma relação de senhoria material que enseja os atos de fruição e de apropriação econômica no interesse próprio; empresário, assim se qualificando, assume a álea da empresa e, por conseguinte, executa a atividade produtora em nome próprio. ${ }^{8}$

A categoria empresário agrícola é assim variada, pois engloba o proprietário, o possuidor, o usufrutuário, o arrendatário, o parceiro - outorgado, o concedente.
5 Id., ibid., p. 29.
6 Id., ibid., p. 30.
7 Id., ibid., p. 34.
8 Id., ibid., p. 44. 
Ao contrário, não são empresários agrários os proprietários de bens concedidos em usufruto, nem os proprietários ou usufrutuários de bens arrendados, dados em parceria, nem os arrendatários de bens subarrendados.

A distinção entre empresário-proprietário e empresário nãoproprietário, terminologia acolhida pelos chamados economistas da agricultura, não é privada de relevância jurídica. ${ }^{9}$

Ressalte-se que, através do reconhecimento da empresa agrária como instituto central do Direito Agrário, conclui-se que o imóvel rural se enquadra como bem de produção, na medida em que passa a prevalecer a idéia do desdobramento da unidade econômica, representando a propriedade o ângulo estático, reservada a empresa o ângulo dinâmico do mesmo fenômeno, coordenando-se, assim, a idéia do bem, $o$ imóvel rural, com o sentido de produção, representado pela empresa. ${ }^{10}$

Daí prevalecer a idéia de constituir a empresa agrária uma universalidade de fato do mesmo modo como o são as empresas comercial e industrial. A empresa agrária, observada a estruturação de sistema destinado à produção de gêneros de origem agropecuária, confirma um todo organizado cuja coordenação, disposta de certa forma, constitui aquilo que se pode entender por universalidade de fato. ${ }^{11}$

biológica.

Hoje, ao invés de agropecuária, optamos pela expressão agro-

A empresa agrária resulta da conjunção de terra, investimento nela realizado e destinado à produção, da organização do trabalho desenvolvido no bem imóvel, dos bens móveis e semoventes nela existentes, os elementos integrados que determinam a destinação à produção. Tais elementos, analisados em conjunto e sistematizados, visam à produção de bens com o intuito de lucro. A idéia de universalidade de fato corresponde ao instituto que reúne o conjunto de bens de que se compõe a empresa agrária. ${ }^{12}$

A noção de empresa agrária se submete a atualizações para integrar formas emergentes de atividade agrária, o que representa, aproximação significativa

9 Id., ibid., p. 44, indica normas legais aplicáveis aos sujeitos de Direito Agrário, arts. 2.137, 2.088 e seguintes e 838 do Código Civil italiano.

10 Scaff, Fernando Campos, A Empresa e o Direito Agrário, em Revista de Direito Civil, Imobiliário, Agrário e Empresarial, n. 57, ,pp. 61-2, julho-setembro de 1991.

11 ld., ibid., p. 62.

12 Id., ibid., p. 62 
e importante àquele que é o sistema comunitário europeu de disciplina da agricultura. Relevante assinalar é a consciência da necessidade de se adotar um critério objetivo e mercealógico, como o fez o sistema comunitário referido, o que consente a superação de controvérsias em torno da agrariedade desta ou daquela atividade. $^{13}$

2 - Diferença entre empresa agrária e sociedade comercial tendo por escopo atividade agrária.

A empresa agrária pode servir-se de qualquer forma prevista para as empresas comerciais ou não-comerciais; entre as não-comerciais há o modelo da sociedade simples.

As formas de sociedades comerciais serão, sobretudo, preferidas para as atividades de alienação e de transformação, as quais devem estabelecer, necessariamente, relações mais intensas externamente. ${ }^{14}$

Os empresários rurais estão livres para escolher as formas societárias mais idôneas aos fins perseguidos; contudo na disciplina dos vários tipos não está prevista nenhuma adaptação para as exigências particulares da agricultura.

A qualificação de empresário agrário não se aplica quando dois ou mais empresários fundam uma sociedade para a transformação ou a venda dos produtos de seu fundo ou a criam para operar na aquisição de bens necessários aos seus estabelecimentos ou, em geral, para o exercício de uma atividade não essencialmente agrária. Mas este tipo pela norma do art. 2.135 do Código Civil italiano seria qualificável como agrária, porque conexa ou considerada conexa da agricultura, criação de animais, silvicultura. Acrescente-se as atividades agrárias inseridas na noção de agricultura biológica e as atividades agrárias atuantes sem terra. $^{15}$

Quando se caracterizar o acima descrito, a atividade social não pode ser considerada agrária, porque a empresa, o empresário, não estão opèrando nem na área da agricultura, nem na silvicultura, nem na criação ou seja em nenhuma das

13 Di Pepe, Giorgio Schiano, Impresa agricola e agrarietà, rm L'impresa agricola, Milano: Giuffrè Editore, p. 159, 1978,

14 Id., ibid., p. 160.

15 Casadei, Ettore, ob. cit., p. 34. 
atividades idôneas a qualificar a empresa como agrária, nem mesmo se trata de existência da atividade conexa. ${ }^{16}$

3 - Obrigações do empresário agrário.

As obrigações, como se apontou, são as mesmas quer se trate de empresário-proprietário, quer empresário não-proprietário.

A ambos cabe a obrigação pela conservação do solo, preservação das reservas naturais, manter o fundo agrário produtivo, constituindo tais deveres verdadeiras tarefas a executar.

O cumprimento de referidas obrigações pressupõe que o bem produtivo - a terra - integre o estabelecimento e daí decorre existir a empresa.

A autonomia do titular do domínio ou do direito de usar fundo agrário para exercer ou cessar uma atividade econômica não é ilimitada, porém, não pode descuidar da destinação do bem agrário.

Há, contudo, respeito à vontade individual quanto à criação e cessação de empresas agrárias, quanto à plena iniciativa de escolha da destinação econômica e sua transformação ou até de mudar sua destinação. ${ }^{17}$

O proprietário de um fundo idôneo ao cultivo, mas inculto, não está obrigado a exercitar uma empresa de cultivo ou o proprietário de um fundo cultivado proibido de transformá-lo em um parque, jardim, reserva de árvores, plantas, etc.

O que ao proprietário é vedado é o abandono da conservação ou do cultivo, pois tal comportamento negativo causa a depreciação progressiva do bem, o que deve ser obstado quando repercute danosamente na economia.

Daí a sanção: a expropriação. Esta atinge o proprietário e não o empresário, porque se a gestão do bem produtivo cabe à personalidade econômica do empresário, a atividade de conservação diz respeito ao proprietário. ${ }^{18}$

O que acaba de ser asseverado vale, também, quando não coincidam as duas pessoas econômicas em uma única pessoa (física ou jurídica), quando a conservação seja confiada pelo proprietário ao empresário, usufrutuário, arrendatário, parceiro - outorgado, mas, nesse caso o proprietário, desejando retomar

16 Id., ibid., p. 45.

17 Id., ibid., p. 45.

18 Id., ibid., p. 45. 
o fundo agrário, no estado em que o entregou, é legitimado para reclamar do empresário a atividade conservadora a que se obrigou. ${ }^{19}$

A inércia do proprietário leva-o a sofrer sanção seja quando deixa o exercício da atividade econômica, descuidando de dar ao fundo destinação útil, seja quando negligencia em suprimir o direito do empresário que abandonou o cultivo, a destinação acordada. ${ }^{20}$

O empresário está obrigado a tutelar as condições de trabalho de seus empregados. É a ligação entre o Direito do Trabalho e o Direito Agrário. Esta obrigação é prevista na legislação agrária brasileira.

O empresário está obrigado a assegurar as condições objetivas necessárias ou úteis para a proteção da saúde dos trabalhadores. Fala-se, atualmente, em Direito Agrário sanitário.

4 - As empresas coletivas agrárias.

Empresa coletiva agrária é aquela onde a titularidade pertence contemporaneamente a vários sujeitos.

Existem vários tipos de empresas coletivas agrárias.

1 - Vários proprietários ou usufrutuários ou arrendatários ou parceirosoutorgados utilizam, conjuntamente, suas terras com os fins de uma gestão comum, objetivando dividir as rendas em proporções às quotas respectivas.

2 - Várias pessoas se unem com o escopo de obter capital para adquirir terra, para constituir a empresa que, após, gerem unitariamente; o exemplo mais importante reside nas cooperativas de trabalho, mediante as quais trabalhadores (comumente braçais) se associam para adquirir uma herdade ou obtê-la em arrendamento ou parceria.

3 - A empresa coletiva soluciona o problema da organização do trabalho, por exemplo, como quando o titular do direito de fruição do fundo rústico diligencia fixação de forças laborativas, não através de contrato de trabalho, mas,

19 Id., ibid., p. 45.

20 O Direito italiano prevê que a inobservância, pelo empresário, das obrigaçðes pode levá-lo à suspensão do exercício da empresa ou a se nomear um administrador que assuma a gestão ou se for pessoa jurídica que haja a substituição dos administradores, como dispre o art. 2.091 do Código Civil italiano. 
mediante associação com um grupo de trabalhadores, os quais, conjuntamente com o empresário, dirigem a empresa e dividem os riscos e proveitos.

4 - Tendo presente a combinação descrita no item anterior, as empresas de parceria agrária oferecem exemplos. Serão empresas coletivas de cultivo, nas quais o estabelecimento se organiza através de associação de capital e trabalho.

5 - A empresa de parceria pecuária apresenta, às vezes, o exemplo de uma empresa coletiva para criação de animais, resultante da associação com um capitalista ao mesmo tempo trabalhador rural; a parceria rural simples corresponde, provavelmente, a uma associação com participação sendo o parceiro outorgante o titular da empresa.

6 - Particular forma de pequena empresa coletiva de cultivo configurase cada vez que a empresa é exercida por uma família.

7 Empresas coletivas dirigidas a satisfazer fins determinados ou exigências especiais de gerência. ${ }^{21}$

8 - Há, também, empresas constituídas por agricultores com o escopo de aquisição de produtos, mercadorias, instrumentos rurais e máquinas; existem, outrossim, empresas geridas por uma coletividade de produtores agrícolas, cujo escopo é a transformação e venda de produtos pelas várias empresas de cultivo. Exemplos são fábricas de queijo e cantinas, dirigidas por produtores de queijo e uva. Tais empresas serão agrícolas apenas quando a atuação da cantina e fábrica de queijo se enquadrem no exercício normal da agricultura da região.

Para que uma empresa coletiva exista é necessário que sua atividade seja exercida, profissionalmente, em nome e por conta de todos os empresários agrários; que cada um colabore mediante concessões para a constituição do organismo produtivo e assuma a álea concorrendo nos ganhos e nas perdas. ${ }^{22}$

Ressalte-se, contudo, quando a coletividade dos empresários se constitui em pessoa jurídica é inexato falar-se em empresa coletiva. Aí, o ente, o novo sujeito, será o titular da empresa, em seu nome e por sua conta a gestão é conduzida e apenas o novo sujeito assume as obrigações e se beneficia com os direitos. $^{23}$

21 Casadei, Ettore, ibid., p. 31.

22 Id., ibid., p. 31.

23 Id., ibid., p. 31. 
Neste tipo de empresa coletiva típica da atividade agrária, originada em suas várias formas, no exercício dos contratos de parceria, parceria pecuária $\mathrm{e}$ contrato de trabalho agrário, a disciplina que a rege está toda polarizada na relação interna entre coempresários, sendo certo que a atividade negocial se apresenta, quase sempre, como um aspecto marginal da empresa. ${ }^{24}$

Estas empresas coletivas agrárias constituem a mais típica expressão da empresa agrária; em sua essência é, principalmente, uma forma de utilização do fundo, enquanto a empresa comercial é sempre atividade desenvolvida per negociationes.

5 - As associações de empresas agrárias.

Para alcançar escopos lucrativos às respectivas empresas, os empresários agrários se associam e constituem novas empresas.

Tais associações, normalmente reconhecidas como pessoas jurídicas, alcançaram um desenvolvimento importante a ponto de se terem transformado numa das maiores expressões da tutela e da defesa da atividade agrária nos mercados.

A maior parte da atividade negocial que tem por objeto os reabastecimentos para o agricultor e a alienação de seus produtos agrícolas se desenvolve através de associações com esta conformação.

Tais associações, geralmente, não são qualificáveis como empresas agrárias.

Podem ser reagrupadas, conforme seu escopo, segundo Ettore Casadei, do seguinte modo: ${ }^{25}$

a. associações destinadas a alienar produtos agrícolas (consórcios agrários e cooperativas);

b. associaç̃ões que exercem atividade dirigida à transformação dos produtos agrícolas e a alienação de produtos transformados (sociedades cooperativas para a gestão de fábricas de queijo, cantinas, fabricação de óleo, dessecadores de gordilhão de lã, casulos ou de tabaco);

24 Id., ibid., pp. 31-2.

25 Id., ibid., p. 34. 
c. associações fornecedoras aos agricultores de máquinas, instrumentos, sementes, adubos, anticritogâmicos, mercadorias e materiais úteis ao exercício da agricultura (consórcios, cooperativas, etc.);

d. associações que objetivam a concessão de crédito em favor dos agricultores (sociedades cooperativas que gerem caixas sociais, consórcios agrários);

e. associações com atividade securitária em favor dos agricultores (sociedades de seguro contra os riscos do granizo e doenças de animais);

f. associações prestadoras de serviços diversos de caráter assistencial em favor de agricultores associados (associação nacional de cultivadores de plantas herbáceas, plantas oleaginosas, associação nacional de tabacocultivadores, ente assistencial de usuários de motores agrícolas, etc);

g. associações que desenvolvem atividades dirigidas à transformação fundiária (consórcios de melhoria fundiária).

Quanto às entidades sob a letra $c$, assinale-se, que quando aperfeiçoam aquisições em nome próprio para revenda de mercadorias aos sócios, configuram indubitavelmente uma atividade de intermediação na circulação dos bens, e, pois, são consideradas empresas comerciais.

As entidades sob as letras $d, e$ e $f$ desenvolvem em favor dos sócios, empresários, uma série de atividades diversas, nenhuma das quais possa ser considerada agrária; as atividades creditícia e securitária são irrefragavelmente comerciais. ${ }^{26}$

A classificação de entidades sob a letra $g$ exige análise mais detida.

A obra de adaptação do solo ao cultivo parece desde logo não se diferenciar do cultivo, mas, quase sempre nessa compreendida como uma das atividades de que o ato de cultivar se compõe, de modo a não se considerar utilmente distinta.

As obras de regulação das águas, de viabilidade de alqueive, as construções edilícias, são obras que o próprio agricultor executa, a medida que cultiva o fundo, tornando-o mais apto ao cultivo; são pequenas e grandes melhorias. ${ }^{27}$

Há, porém, casos, a propósito infreqüentes, em que a atividade de adequação do solo apresenta-se com caracteres particulares, seja porque é executada,

26 Id., ibid., p. 35.

27 Id., ibid., p. 35. 
separadamente na época do cultivo, quando a época deste se finalizou, ou quando se refere a áreas nunca antes submetidas a plantio, ou porque fora explorada por outra empresa. ${ }^{28}$

A natureza da atividade pode ser modificada quando há cisão dos sujeitos da atividade agrária (pessoa jurídica do consórcio e as pessoas físicas dos consorciados).

A execução das obras de adequação fundiária, quando é efetuada pelo próprio titular da empresa que cultiva (isto ocorre, particularmente, nas pequenas transformações fundiárias, limitadas a um único estabelecimento e que se configuram em melhoria do sistema agrário existente) constitui atividade dirigida à atuação do estabelecimento e, pois, incindivelmente coligada ao da organização e do exercício da empresa agrária.

As relaçðes jurídicas encetadas pelo titular da empresa de cultivo com quem dispõe do fundo são agrárias, do mesmo modo o são as atividades direcionadas a melhorar as condiçð̃es de aproveitamento da herdade.

Quando as melhorias são assumidas e executadas por um consórcio, por sujeito de direito diferente do empresário titular das empresas agrárias investidas na exploração do fundo, esta atividade de transformação fundiária está despojada de qualquer caráter agrário.

A atividade de beneficiamento do solo é objeto de incumbência atribuída a uma empresa industrial, as atuaçðes das duas empresas a que executa a benfeitoria e a que explora o fundo - são nitidamente distintas, como distintos são os seus produtos; uma visa beneficiar o terreno e a outra a exploração agrícola racional do solo. ${ }^{29}$

6 - O pequeno empresário agrário.

O trabalho como fator de produção nunca falta numa empresa agrária e não é irrelevante a circunstância de que o trabalho seja fornecido pessoalmente pelo empresário e pelos seus familiares ou que o obtenha junto a terceiros. ${ }^{30}$

28 Id., ibid., p. 36.

29 Id., ibid., p. 36.

30 Id., ibid., p. 39. 
$\mathrm{Na}$ primeira eventualidade, estamos perante o tipo econômico do cultivador direto, objeto de muitas normas legais, mas não é o único exemplo de empresário agrário que forneça, pessoalmente, o trabalho necessário para o exercício da empresa ou o obtenha na família, vez que tal fenômeno se verifica não-só nas empresas dedicadas ao cultivo, mas, também, nas empresas zootécnicas e naquelas cujo objeto é a silvicultura. Mas a presença do trabalho como fator de produção está mais presente no primeiro tipo econômico a despeito da presença cada vez mais atuante da mecanização.

A análise deve-se concentrar na figura do cultivador direto, mas as consideraçðes, a seguir desenvolvidas, concernem a outras figuras de agricultor, apesar das adaptaçð̃es que se impð̋em, mas, num sentido mais amplo, que são suscetíveis de serem enquadradas na primeira mencionada. ${ }^{31}$

A empresa de cultivador direto se caracteriza por dois interesses fundamentais: o primeiro é empregar o trabalho familiar no estabelecimento, dentro dos limites os mais extensos possíveis; o segundo é de prover, diretamente, ao que é necessário sob o aspecto doméstico, com a consequência de uma limitação nas trocas com o exterior e a presença de atrofia na atividade negocial da empresa, acentuada pelas escassas possibilidades financeiras.

Para traçar um paralelo entre a empresa de cultivador direto, que emprega o trabalho familiar e a que se vale de trabalhador alheio, esta com caracteres extrínsecos, às vezes semelhantes aos existentes nas empresas industriais, temos: neste tipo que se vale do trabalhador alheio trata-se de empresas de grande arrendatário ou proprietário que se vale de mão-de-obra assalariada e mais numerosa, onde o recurso ao crédito é maior e mais frequente, onde o escopo de especulação é mais evidente, a produção sendo destinada quase exclusivamente ao mercado. $^{32}$

Ettore Casadei ensina que a configuração do cultivador direto enquadra-se perfeitamente na definição de pequeno proprietário.

$\mathrm{Na}$ empresa do cultivador, o trabalho é, em regra, fornecido pela família, mas, também, por uma comunidade de trabalhadores dirigida e que obteve eficácia, através da orientação do empregador apesar de o emprego da mão-de-obra estranha manter, sempre, uma função complementar, por sua natureza excepcional e

\footnotetext{
31 Id., ibid., p. 39.

32 Id., ibid., p. 39.
} 
transitória, recorrendo-se a ela nos momentos em que a família cultivadora não baste às necessidades do estabelecimento. ${ }^{33}$

A unidade laborativa permanece de caráter familiar, enquanto $o$ trabalho oferecido pela família continue sempre predominante sobre o proveniente do exterior, mesmo quando o trabalho fornecido pelos estranhos seja permanente na empresa do cultivador direto, isto é, não tenha caráter irregular, em relação às irregularidades das estações do ano e do diagrama anual do trabalho. Trata-se, sempre, de forças acrescidas à família que não se alteram. ${ }^{34}$

Esta noção de cultivador direto abrange o arrendatário ou parceiro outorgado, cultivador direto do fundo com trabalho prevalecentemente, próprio e de pessoas de sua família.

$\mathrm{Na}$ pequena empresa em geral e, portanto, na pequena empresa agrária, o trabalho executado pelo sujeito da relação agrária, por conta própria e no próprio interesse, não é alçado na avaliação jurídica à natureza de bem e mesmo concorrendo sob o ponto de vista econômico, com todos os outros elementos da produção, parece não figurar como bem sob o ponto de vista jurídico. ${ }^{35}$

A consideração permanece verdadeira, também, quanto às prestações executadas pelos familiares e exigidas pelo empresário familiar, para que tenham 0 direito de utilizar o estabelecimento e em vantagem da família. As energias laborativas e a prestação de trabalho da mulher e dos filhos menores não é considerada um bem objeto de particular relação jurídica.

A estrutura familiar não muda ao se recorrer ao trabalho alheio por exigências marginais e excepcionais ou mesmo constantemente, desde que em quantidades tais a não configurar forças predominantes da empresa. ${ }^{36}$

A relação entre capacidade de trabalho dos cultivadores e a necessidade de trabalho do fundo, face às consequêencias do desenvolvimento da técnica, pode ser modificada.

33 Id., ibid., p. 40.

34 Id., ibid., p. 40.

35 Id., ibid., p. 40.

36 Id., ibid., p. 40. 


\section{Contrato agrário e empresa agrária.}

O contrato agrário permite que o futuro empresário não-proprietário utilize o solo que é o núcleo central ao redor do qual se dispõem organicamente todos os outros bens destinados ao exercício da empresa agrícola.

$\mathrm{O}$ contrato agrário, às vezes, serve para alcançar não apenas a fruição do fundo, mas pode se constituir no embrião do estabelecimento que seria o fim mais freqüentemente perseguido. A constituição do estabelecimento pode não ser o fim almejado por ele já existir e ser operante como ocorre com o arrendamento de um fundo equipado e pronto para desenvolver a sua função produtiva, neste caso o estabelecimento já existe e através do contrato agrário se possibilita a fruição por parte do concessionário. ${ }^{37}$

8 - A noção de unidade produtiva.

Unidade produtiva é o objeto do contrato de arrendamento e não mais o fundo tradicional, reavaliada economicamente e gerida em sintonia com as exigências da assim denominada nova agricultura, em medida tal que justifique a redução dos contratos agrários (instituto pelo qual um negócio jurídico que objetiva atividade agrária se transforma em arrendamento).

Unidade produtiva se caracteriza pelas condições objetivas de rentabilidade ou produtividade que permitam a formação de uma empresa agrária válida sob o perfil técnico e econômico.

A sanção quando o fundo objeto de contrato associativo não constitua, nas suas condiçð̃es atuais ou em seguida à execução de um plano de desenvolvimento empresarial, uma unidade produtiva será a conversão do contrato de parceria em arrendamento, conforme o modelo adotado na moderna legislação agrária italiana, em cumprimento às disposições comunitárias que motivaram mudanças legislativas em outros países da Comunidade. ${ }^{38}$

\section{Id., ibid., p. 3.}

38 Salaris, Fernando, "La riduzione al" tipo unico dei contratti agrari" Torino, G Giappichelli, 1989 , p. 85 . O art. 31 da lei italiana n. 203/82 regula os parâmetros para a configuração de unidade produtiva. Esta lei reduziu os contratos agrários ao arrendamento. Adaptando a noç̃o de unidade produtiva ao Direito brasileiro diremos que a unidade produtiva tem por objeto os contratos agrários como regulados na legislação especial. 
A unidade produtiva é um ponto de referência que concerne à renda do trabalho na agricultura, sempre comparável com a renda do trabalho em alguns setores produtivos. A unidade produtiva se revela, sem dúvida, adequada aos objetivos de uma agricultura moderna. ${ }^{39}$

A reavaliação da unidade produtiva em agricultura - objeto do arrendamento - encontra sua fonte, também, nos programas de política no âmbito da Comunidade Econômica Européia.

A quantidade de terreno de que o empresário dispõe, para alcançar o nível de unidade produtiva, deve consentir na obtenção de uma renda comparável com aquela de uma unidade extra-agrícola. ${ }^{40}$

É necessário que o empresário agrícola disponha não-somente de uma extensão de terra capaz de lhe consentir a obtenção de uma renda mínima mas, também, disponha de uma unidade idônea a produzir validamente. No mesmo sentido as diretrizes da política agrícola da Comunidade Econômica Européia, com referência à melhoria das estruturas agrárias produtivas, cuja funcionalidade prevalece sobre a tutela da propriedade do fundo. ${ }^{41}$

$\mathrm{O}$ instituto da unidade produtiva equivale no Direito brasileiro ao instituto do módulo rural ou aos índices GUT para avaliar o grau de produtividade da terra como previsto no Estatuto da Terra ou nas decisð̃es normativas dos órgãos federais competentes.

Os institutos da unidade produtiva, mínima unidade cultural, módulo rural, propriedade familiar, exigem uma nova concep̧̧ão das dimensð̃es do estabelecimento agrário por causa da mecanização e especialização das culturas.

No passado havia uma economia de consumo, conexa à família campesina, a qual produzia bens mais para si do que para o mercado. A produtividade competitiva no mercado interno e internacional constitui um novo parâmetro de quem dirige uma empresa agrária.

O trabalho não mais tem o escopo de obtenção de bens de consumo essenciais, mas é um fato produtivo e deve ser avaliado com base no seu custo e sua renda. Não apenas a renda da unidade produtiva prevaleceu sobre a familiar, mas a mecanização do processo produtivo que multiplica a potencialidade laborativa da

39 Id., ibid., p. 86.

40 Id., ibid., p. 86.

41 Id., ibid., pp. 92-3. 
unidade empresarial. Esta se transforma não apenas sob o perfil econômico, mas particularmente sob o técnico. ${ }^{42}$

$O$ instituto da unidade produtiva desloca a importância da função social da terra para a função social da empresa agrária com a amplidão e ausência de formalidades objetivadas na regulação desta última.

A eficiência da unidade produtiva está estreitamente conexa à tutela do meio ambiente. As novas técnicas produtivas, com efeito, se não forem racionalmente controladas, podem conduzir a exploração intensiva da unidade fundiária com critérios irracionais, pois, anti-sociais e antieconômicos. Subsiste então uma correlação entre a eficiência produtiva e a conservação e melhora do meio ambiente, onde a empresa agrária opera. ${ }^{43}$

A unidade produtiva se revela instrumento eficaz contra a degradação da terra. ${ }^{44}$

9 - Empresa Agrária no Direito Brasileiro.

No Direito brasileiro Emilio Alberto Maya Gischkow se ocupou com o tema empresa agrária. ${ }^{45}$

Aceita a orientação de que a empresa rural passou para uma posição de preeminência, deslocando-se a propriedade rural para um segundo plano. Fundamenta a modificação porque: "as relações jurídicas no Direito Agrário são impositivas, cogentes, evidenciando a prevalência de um critério publicístico, submetendo o sujeito de direito à precedência do interesse social e a transcendência dos fatores econômicos de progresso e desenvolvimento. " 46

O legislador pátrio, a partir de 1964 e com a reforma das normas agrárias, optou por entender que a "utilização do solo para fins produtivos foi colocada, no plano positivo, como conceitualmente distinta do exercício dos poderes e direitos de propriedade da terra." 47

42 Id., ibid., pp. 102-3.

43 Id., ibid., p. 122.

44 Id., ibid., p. 136.

45 Gischkow, Emílio Alberto Maya, Princípios de Direito Agrário-Desapropriação e Reforma Agrária, São Paulo: Saraiva, 1988.

46 Id., ibid., p. 143.

47 Id., ibid., p. 143. 
Ressalta que "a empresa", no campo do Direito Agrário, "é uma instituição que deve servir principalmente ao trabalhador", daí concluir que "o trabalho seria valorizado hierarquicamente a ponto de ser considerado como elemento principal da organização empresarial. A empresa seria contemplada como autêntica comunidade de trabalho e produção. O trabalho humano seria o título mais legítimo para caracterizar o direito de propriedade." 48

O conceito de empresa rural para o Direito brasileiro consta do art. $4^{\circ}$, inciso VI do Estatuto da Terra, Lei n. 4.504, de 30 de novembro de 1964: "VI "Empresa Rural" é o empreendimento de pessoa fisica ou jurídica, pública ou privada, que explore econômica e racionalmente imóvel rural, dentro de condição de rendimento econômico ... de região em que se situa e que explore área mínima agricultóvel do imóvel segundo padrões fixados, pública e previamente, pelo Poder Executivo. Para esse fim, equiparam-se às áreas cultivadas as pastagens, as matas naturais e artificiais $e$ as áreas ocupadas com benfeitorias".

O enunciado da concepção do legislador brasileiro de empresa rural demonstra tratar-se de noção vinculada à propriedade fundiária, à submissão aos parâmetros da sua função social.

Basta ler o parâmetro determinado no art. 44 do Decreto n. 72.106, de 18 de abril de 1973: "art. 44. O imóvel rural será classificado como empresa rural, na forma do disposto no art. $4^{\circ}$, item VI, e art. 50, $\S 7^{\circ}$, da Lei $n$. 4.504, de 30 de novembro de 1964, desde que sua exploração satisfaça às seguintes exigências: I que a área utilizada nas várias explorações represente porcentagem superior a $70 \%$ (setenta por cento) de sua área agricultóvel, equiparando-se, para esse fim, às áreas cultivadas as pastagens, as matas naturais e artificiais $e$ as áreas ocupadas com benfeitorias: II - que obtenha coeficiente de condições sociais e de produtividade igual ou inferior a l (hum)."

Já o art. 22, inciso III do Decreto n. 84.685, de 6 de maio de 1980, estatui: "Empresa Rural, o empreendimento de pessoa fisica ou jurídica, pública ou privada, que explore economicamente e racionalmente imóvel rural, dentro das condições de cumprimento da função social da terra e atendidos simultaneamente os requisitos seguintes: a) tenha grau de utilização da terra igual ou superior a $80 \%$ (oitenta por cento), calculado na forma da alínea a do artigo $8^{\circ}$; b) tenha grau de eficiência na exploração, calculado na forma do art. 10, igual ou superior a 
100\% (cem por cento); c) cumpra integralmente a legislação que rege as relações de trabalho e os contratos de uso temporário da terra."

A empresa rural, como regulada entre nós, se diferencia do que desenvolvemos neste capítulo ao analisarmos o instituto como concebido na legislação e doutrina italianas, onde nasceu e se desenvolveu a estruturação da empresa agrária, influenciando de modo acentuado o entendimento da matéria.

A insuficiência do conceito legal que trata de empresa rural e não de empresa agrária foi detectada por Emilio Alberto Maya Gischkow ao apontar: "Para encontrar fórmula capaz de propiciar o conceito de empresa rural, sustenta-se que seria a caracterizada como forma associativa de produção, na qual as participações de capital e trabalho se realizariam em igualdade de condições, assegurando aos associados a co-propriedade dos rendimentos $e$ as responsabilidades de gestão, administração e trabalho." ${ }^{49}$

A concepção de empresa rural no direito positivo brasileiro engloba a chamada propriedade familiar, instituto previsto no art. $4^{\circ}$, II do Estatuto da Terra: "Propriedade Familiar" o imóvel rural que, direta e pessoalmente explorado pelo agricultor e sua familia, lhes absorva toda a força de trabalho, garantindo-lhes a subsistência e o progresso social e econômico, com área máxima fixada para cada região e tipo de exploração, e eventualmente, trabalho com a ajuda de terceiros;"

Emilio Alberto Maya Gischkow inclui a propriedade familiar como definida acima como tipo de empresa rural pois: "Não existe dúvida em que o Estatuto da Terra, no plano legal, admite a propriedade familiar como empresa rural, desde que o imóvel rural garanta a subsistência e o progresso social e econômico do agricultor e sua família", calçado na lição do pioneiro e saudoso mestre Fernando Pereira Sodero. ${ }^{50}$

Sodero aponta que o instituto da propriedade familiar é organizado em empresa rural e invoca a lição de Antonio Ballarin Marcial referindo-se, ao Estatuto da Terra, que implantará um sistema de agricultura empresarial, de base familiar e associativa. $^{51}$

49 Id., ibid., p. 146.

50 Id., ibid., p. 147

51. Sodero, Fernando Pereira, Direito Agrário e Reforma Agrária, 1ª, ed., São Paulo, Livraria Legislação Brasileira, p. 92, 1968. 
Paulo Torminn Borges não insere a propriedade familiar no quadro da empresa rural, definindo-a como a unidade de produção para conjunto familiar enquanto define a empresa agrária como "unidade de produção para uma comunidade mais ampla, onde se associam terra, trabalho, capital e técnica, tudo dirigida organicamente a um fim econômico." 52

Paulo Torminn Borges, ao abordar a natureza da empresa rural, indica ser de natureza civil e depender de registro. E ressalva: "salvo, evidentemente, quanto à natureza, que será comercial se a empresa girar sob a forma de sociedade anônima." 53

No mesmo sentido Luís de Lima Stefanini. ${ }^{54}$

Luís de Lima Stefanini nota que a lei agrária brasileira "não expendeu um conceito jurídico de empresa, mas um conceito econômico, que, a parte isso, congrega, também, falhas lamentáveis." 55

Entre nós, o professor Waldírio Bulgarelli ensina que a empresa agrária atinge certo grau de desenvolvimento e passa naturalmente para o âmbito empresarial comum, geralmente através da adoção da forma de sociedade anônima, tipo societário que a comercializa obrigatoriamente.

Fala numa visão quantitativa que está "continuamente presente, como se pode verificar desde logo pela noção de empresa rural do Estatuto da Terra em que procurou conceituá-la através dos critérios de rentabilidade e de dimensão, ficando inserida entre o minifúndio e o latifúndio." 56

$\mathrm{O}$ eminente jurista ressalta que o Direito Fiscal não ficou imune às considerações quantitativas, tanto que o Dec. 66.095 , de 20.1.70 sobre o Imposto de Renda das propriedades rurais, estabeleceu três faixas de receita para efeito de contabilidade: até 600 vezes o maior salário mínimo, basta a declaração por

52 Borges, Paulo Torminn, Institutos Básicos do Direito Agrário, $4^{\mathrm{a}}$ ed. rev. e at., São Paulo, Saraiva, p. 62, 1983.

53 Id., ibid., p. 65.

54 Stefanini, Luís de Lima, A Propriedade no Direito Agrário, São Paulo, Editora Revista dos Tribunais, p. 287.

55 Id., ibid., p. 278.

56 Bulgarelli, Waldírio, A Teoria Jurídica da Empresa (análise jurídica da empresariedade), São Paulo, tese, p. 43t, 1984. 
estimativa; de 600 até 6.000 , exige escrituração rudimentar ou simplificada e de mais de 6.000 exige a contabilidade regular. ${ }^{57}$

O ilustre comercialista caracteriza a especialidade da empresa agrária baseada na visão quantitativa, a qual se revela nos dois aspectos: rentabilidade e dimensão.

Pela redação final do Projeto de Código Civil brasileiro, aprovado pela Câmara dos Deputados, no art. 969: "Considera-se empresário quem exerce profissionalmente atividade econômica organizada para a produção ou a circulação de bens ou de serviços", o que levou Waldírio Bulgarelli a asseverar que "ligada à agrariedade, demonstrando a dualidade de perspectiva do exercício dessa atividade, ora, pelo aspecto da produção ora, pelo aspecto geral ou da distribuição." 58

O referido Projeto de Lei n. 634-B. de 1975, em sua redação final, define no art. 973, I: "o empresário rural, assim considerado o que exerce atividade destinada à produção agrícola, silvicola, pecuária e outras conexas, como a que tenha por finalidade transformar ou alienar os respectivos produtos, quando pertinentes aos serviços rurais", o que levou o Professor Waldírio Bulgarelli a concluir pela exclusão da atividade extrativa. ${ }^{59}$

Comenta o regime do Projeto concluindo que "embora reconhecendo o exercício da atividade rural como empresária, dispensou o empresário rural" de inscrição e das restrições e deveres impostos aos empresários inscritos (art. 1.007, caput), admitindo entretanto, que aquele "cuja atividade rural constitua sua principal profissão" requeira sua inscrição no Registro de Empresa, ficando após a inscrição, "equiparado para todos os efeitos ao empresário sujeito a Registro" (art. 1.008). Certamente, que não passara incólume, sem interpretações contraditórias, a expressão "principal profissão" que bem poderia ter sido dispensada. O art. 1.007, caput, corresponde ao art. 973, caput e o art. 1.008 ao art. 974 da redação final do Projeto de Lei n. 634-B de 1975, publicado D.O.U. em 17 de maio de 1984.

Apontamos o caráter especial da empresa agrária como regulada no Código Civil italiano, o que se repete quatro décadas após no Projeto de Código

57 Id., ibid., p. 431, nota 194. Na mesma perspectiva consultar Luís de Lima Stefanini, ob. cit., pp. $279,280,282$ e 283.

58 Bulgarelli, Waldírio, ibid., p. 433.

59 Id., ibid., p. 433. 
Civil brasileiro, daí a conclusão do professor Waldírio Bulgarelli: "Tem-se pois um regime facultativo instituido pelo Projeto que irá atuar cumulativamente com o regime implantado pela legislação que integra o chamado Direito Agrário. Não vemos nessa orientação nenhum desacerto, apresentando-se coerente a posição do Projeto, levando-se em conta, de um lado, a realidade complexa da agrariedade brasileira e, de outro, a existência de um sistema legal voltado para o exercício da atividade produtiva, passando, inclusive, pelo âmbito das obrigações, através dos contratos agrários e dos títulos de crédito rural. Enquanto o setor rural não alcançar um harmônico desenvolvimento, adquirindo condições às suas empresas de ingressarem plenamente no regime da empresarialidade, parece que a fórmula adotada pelo Projeto não merece reparos. " 60 


\section{Capítulo II}

\section{ESTABELECIMENTO AGRÁRIO}

A sequêência lógica é examinar o estabelecimento, a azienda, após a análise da empresa agrária.

Giuseppe Ragusa Maggiore ensina que no âmbito da teoria da empresa, para se apreender a essência da categoria, é necessário proceder ao estudo dos elementos subjetivo e objetivo sendo certo que ao elemento objetivo corresponde o estabelecimento. ${ }^{61}$

Rosalba Alessi esclarece que os elementos do estabelecimento variam igualmente como ocorre com a noção de agrariedade da empresa que não pode ser contraposta à noção de comercialidade da empresa em geral, isto porque a distinção entre agrariedade e comercialidade tende a perder fundamento, mormente quando os processos de integração que cruzam a agricultura acarretam a dificuldade em se identificar, no interior desta, modos de produção típicos e ou peculiares; igualmente, sob o aspecto externo à agricultura visualiza-se que vão desaparecendo os limites que deveriam separar do corpo uno do sistema econômico, notadamente, quando temos presente a relação entre as categorias jurídicas e os fatos econômicos. ${ }^{62}$

$\mathrm{O}$ estabelecimento é um complexo de bens heterogêneos e entre si interdependentes, destinados ao exercício da empresa. Esses bens podem ser de natureza assaz diversa: bens móveis, dinheiro, mercadorias; bens imóveis, terrenos, casas, oficinas; bens imateriais, tais como direitos, razão social, insígnias, marcas, patentes, segredos industriais, patentes de novas espécies vegetais, etc.

O elemento organização é primordial no estabelecimento. Este é um complexo de bens, reunidos pelo empresário para o exercício da empresa, resultante do ato de destinação material levado a efeito pelo empreendedor, pelo qual cada bem

${ }^{61}$ Maggiore, Giuseppe Ragusa, op. cit. p.34.

62 Alessi, Rosalba, L'impresa agricola, em II Codice Civile Commentario, coordenação de Piero Schlesinger, Milano, Giufre Editore, , p.61, 1990 
é posto em combinação com outros com o escopo de permitir o exercício da atividade de produção e troca. ${ }^{63}$

Para Carlos Fuenzalida Vattier trata-se de uma organização patrimonial, estática e objetiva, instrumentalmente ligada ao exercício da empresa agrária, de uma complexidade técnica e dogmática maior que o simples fundo, ou seja, um meio com o qual a atividade econômica do empresário se leva a cabo. ${ }^{64}$

O estabelecimento constitui a projeção patrimonial da empresa: ele é o conjunto de bens, $\mathrm{o}$ instrumento de exercício da atividade empreendedora. $\mathrm{O}$ estabelecimento é um objeto e a empresa é uma atividade.

A natureza unitária do estabelecimento, tal como um complexo orgânico de bens, considerado sob o ponto de vista econômico, é pacífica; o mesmo não ocorre quando se a examina sob o perfil jurídico. ${ }^{65}$

O estabelecimento é disciplinado como objeto de circulação jurídica, como objeto de usufruto, de locação, de tutela contra atos de concorrência desleal. Também são tutelados os direitos de individuação, tais como os sinais distintivos da firma, a insígnia, a marca.

A empresa agrária, no campo da disciplina da empresa, assume posição de pequena relevância, o estabelecimento agrário, por outro lado, nunca concretiza o modelo ao qual se aplique, em sua plenitude, a regulamentação prevista para o estabelecimento em geral. ${ }^{66}$

Para o estudo da matéria recorre-se àqueles aspectos característicos da empresa, da atividade agrária e às diferenças entre empresas agrárias e comerciais. A necessidade de uma tutela dos produtos de mercado apresenta-se com menos intensidade porque a atividade agrária não se desenvolve, essencialmente, através de uma atividade de troca.

O conceito de estabelecimento não é estranho à atividade agrária, mas pelo que se acaba de indicar, essa não se apresenta essencialmente como uma

63 Casadei, Ettore, op. cit. p. 74.

64 Fuenzalida, Carlos Vattier, Concepto y tipos de empresa agraria en el derecho español, $1^{\mathrm{a}}$ ed., Leon, Editora do Colégio Universitário de Leon, ,p.93, 1978.

65 Casadei, Ettore, op. cit. p. 74.

66 Id., Ibid, p. 4. 
atividade de troca. Encontra-se aí a verificação do motivo que impede a aplicação integral da disciplina do estabelecimento em geral ao estabelecimento agrário. ${ }^{67}$

Luigi Costato conclui que a tese que ressalta tão-somente o elemento terra não é convincente. Daí afirmar que sobretudo em relação aos contratos agrários com concessão de terreno, não se poderá ressaltar a terra sem falar no estabelecimento, que, também como complexo de bens, pode ser objeto de arrendamento; ao contrário nas empresas sem-terra, o estabelecimento se impõe e pode ser concedido a terceiros sem que a legislação especial se aplique. ${ }^{68}$

$\mathrm{O}$ fundo equipado não coincide com o estabelecimento. Às vezes foi o empresário e não propriamente o proprietário do fundo quem criou o estabelecimento. ${ }^{69}$

O fundo é um trecho de solo cultivável destinado à produção agrícola. A terra como fator essencial e característico do processo produtivo agrário recebe a denominação de fundo.

A qualificação agrária do fundo não deduzirá da existência da empresa agrária. Assim também será definido o fundo, cultivado por quem não tenha o requisito de empresário, como quando o fundo é cultivado por puras exigências familiares. $^{70}$

O fundus instructus corresponde a um conceito mais extenso de fundo. A atenuação da autonomia da disciplina jurídica a que estão submetidas as pertenças faz com que animais e instrumentos de trabalho sejam integrados ao fundo. Dessa forma, o fundo será guarnecido, provido de um complexo de pertenças. ${ }^{71}$

A tutela do vínculo de pertença não chega, contudo, ao ponto de criar uma unidade substancial, porque a pertença conserva, ainda que atenuadamente, a

67 Id., Ibid., op. cit. p.75.

68 Costato, Luigi, Estabelecimento Comunitario, Padova, CEDAM-Casa Editrice Dott. Antonio Milani, 1989, p.183.

69 Casadei, Ettore, op. cit. p. 75.

70 Id., Ibid., p.49.

71 Id., Ibid., p. 63. 
própria autonomia individual e pode ser objeto de atos e negócios jurídicos separados. $^{72}$

Pode-se definir fundo pressupondo necessariamente a existência de uma organização de bens (estabelecimento agrário), enquanto não é de se excluir a hipótese da existência de um fundo que não integra o estabelecimento.

O terreno cultivável não é terra nua, mas terra e capital nela investido. Pode-se até afirmar ser uma criação do capital como testemunham as culturas irrigadas da planície, as culturas dispostas em degraus na colina.

Há um complexo de relações surgidas com o exercício da empresa, negócios, direitos, garantias, que juntamente com o fundo e outros bens, constituem os elementos do estabelecimento agrário.

O fundo, por sua vez, não se constitui, necessariamente, por um único trecho de terra, mas podem compô-lo vários lotes de terra distintos e separados e mesmo situados longe uns dos outros como, por exemplo, propriedades com áreas cultivadas sitas num vale e outras para pastos e bosques localizados em sítios montanhosos integrando-se, revezadamente, na gestão unitária.

O fundo não coincide com o conjunto de terras de propriedade do empresário, porque pode ocorrer fundos em condomínio de várias pessoas, cada uma das quais é proprietária de outros fundos, elementos de outros estabelecimentos, como também pode ocorrer empresários que sejam proprietários de vários fundos, elementos de estabelecimentos diversos.

A existência de estabelecimentos distintos, geridos por uma mesma pessoa física, origina-se na autonomia da gestão. O outro exemplo é o do empresário que dirige um estabelecimento em sua propriedade e, contemporaneamente, adentra em imóvel alheio, arrendado. ${ }^{73}$

A autonomia de gestão será mais evidente quando se tratar de imóveis distantes entre si, onde as trocas entre herdades tornam-se raras e inteiramente excepcionais. Poder-se-ia, porém, observar que, também nesses casos, ligações entre os fundos não faltam porque as administrações, ainda que separadas, têm bases

72 Id., Ibid., p.64. O capítulo sobre pertenças se encontra a p.63 a 71

73 Id., Ibid., p. 76 . 
comuns e os locais produtivos são dirigidos por diretrizes unitárias que determinam sempre certa coordenação entre cada herdade. ${ }^{74}$

Poder-se-ia responder que, na realidade, são coligações redutíveis a meros reflexos da coincidência dos diversos empresários em uma única pessoa física, não sendo suficientes para negar a independência entre os vários estabelecimentos, por causa da existência de cálculos e balanços econômicos distintos. $^{75}$

A herdade pode não ser propriedade do empresário, pois, para constituir a relação entre empresário e imóvel, basta uma relação possessória que possibilite atos de fruição e de apropriação econômica no interesse próprio. Basta citar o direito pessoal decorrente da existência de contratos agrários, negócios jurídicos que convergem para a organização do estabelecimento. ${ }^{76}$

Eis o caráter peculiar do estabelecimento agrário que, salvo a exceção acima referida, consiste na necessária presença do fundo que representa uma nota diferencial em relação à empresa comercial um pouco atenuada no estabelecimento zootécnico.

Há, porém, a possibilidade de estabelecimentos que exercem, alternativamente, suas atividades em locais diversos, por exemplo, em pastos longínqüos onde se admite que o fundo também esteja presente. ${ }^{77}$

Há como característica neste tipo acima descrito de estabelecimento a mutabilidade do fundo em relação à mobilidade da empresa, o que exsurge como causa de enfraquecimento da relação entre empresa e retira deste a preeminência que lhe cabe em outras empresas agrárias. O liame ainda mais se atenua ${ }^{78}$ quando, em certos períodos do ano, a empresa de pastoreio não mais desfrute o pasto de modo direto, mas passa a se valer de produtos adquiridos. É difícil afirmar se o fundo, nesses períodos, deixa de integrar o estabelecimento, resultado das relações

74 Id., Ibid., p.76.

75 Id., Ibid., p. 77

76 Id., Ibid., p. 77

77 Id., Ibid., p. 77.

78 Id., Ibid., p. 77 
contratuais complexas que se estabelecem entre o pastor de animais e o agricultor, junto o qual o rebanho ou manada passa o inverno. ${ }^{79}$

A título de conclusão sobre as consideraçð̃es a respeito da empresa de pastoreio, note-se o fato de, às vezes, várias empresas atuarem sobre o mesmo fundo e, pois, um mesmo fundo pode abrigar vários estabelecimentos, cada um provido de sua própria regulação e combinação autônoma dos meios produtivos. O exemplo concreto que se pode apresentar é o da empresa de pastoreio, cujo exercício ocorre em pastos em descanso: enquanto o empresário agrícola conduz a empresa de cultivo, o pastor cuida da criação de animais em terreno para pasto, o qual integra outro estabelecimento que, por sua vez, mantém culturas produtivas. ${ }^{80}$

Há uma exceção sobre a presença necessária do fundo rústico: este falta nas empresas zootécnicas, cujas atividades se desenvolvem em sede fixa, independentemente da atividade de cultivo ou quando os alimentos para os animais são trazidos de fora.

Aqui falta a terra, sem que se possa referir ao cultivador, aquele de quem o criador de animais adquire as forragens necessárias, ao mesmo tempo que não exsurgem como elementos do fundo rústico os bens imóveis utilizados pelo empresário (estábulo, depósito de feno, etc). Trata-se de bens de natureza diversa. ${ }^{81}$

Ao retomar o exame dos elementos do estabelecimento, acenemos aos instrumentos fixos: o gado de trabalho, de leite, animais para a obtenção de lã, máquinas e utensílios.

Há, também, os chamados instrumentos circulantes: forragens, leiteiras, estrume, sementes. Entre esses, parte considerável é comumente produzida pelo fundo, enquanto outra é adquirida (especialmente as sementes).

Trata-se de produtos que são, sempre, utilizados no estabelecimento e, portanto, estão constantemente presentes, ou como instrumentos de produção, ou como produtos. $^{82}$

79 Id., Ibid., p.78.

80 Id., Ibid., p. 78 .

81 ld., Ibid., p. 78 .

82 Id. Ibid., p.78. 
A vicissitude cíclica, através da qual se opera a mudança da forma, fornece-lhes a denominação instrumentos circulantes. Sejam instrumentos fixos ou circulantes, inserem-se na categoria das pertenças e, então, sua relação com o fundo adquire precisa relevância jurídica.

Os economistas reúnem outros elementos heterogêneos, concorrentes à formação do estabelecimento em uma classe única, denominada capital por antecipação.

O capital por antecipação, sob o ponto de vista econômico, é o capital representado por um poder de aquisição (em moeda, em créditos, em produtos disponíveis para alienação), de que o empreendedor lança mão para o emprego de outros meios de produção necessários, matérias-primas e auxiliares, serviços exigidos pelo mercado, prestação de trabalho, etc., durante o ciclo de produção em momento precedente à finalização dos produtos. ${ }^{83}$

O capital por antecipação, para o jurista, integra o estabelecimento sob espécies diversas: como bens materiais (normalmente são bens enquadrados como instrumentos), como contratos (de execução contínua ou periódica) ou créditos inerentes ao exercício da empresa. Este capital nunca falta na empresa, não importando a forma mutável que possa assumir e o tipo de pessoa jurídica escolhida. ${ }^{84}$

Ressalte-se que não se pode falar em empresa e estabelecimento no regime de economia fechada e na organização de atividade econômica fechada com fins meramente familiares em que todos os meios de produção sejam adquiridos no mercado. Esses dois tipos de atividade econômica representam os limites para qualquer empresa que se localize num grau intermediário, para o qual correspondem relações jurídicas encetadas com o estabelecimento, onde o capital por antecipação exerce um papel diferente sem o qual haverá apenas fundo equipado e não estabelecimento e, pois, inexistirá empresa se os liames vitais entre o agricultor e o mercado tiverem sido cortados. ${ }^{85}$

83 Id., Ibid. p. 78

84 Id., Ibid., p.78.

85 Id., Ibid., p.79. 
Outros elementos comuns a todo tipo de estabelecimento a razão social, a marca e o fundo de comércio no estabelecimento agrário têm importância reduzida por razões diversas, se comparados com seu relevo no estabelecimento comercial.

À firma, a razão social tem valor dispensável, por causa das características particulares do crédito na agricultura.

Quanto ao fundo de comércio, ele adquire uma característica importante na disciplina do estabelecimento agrário.

O fundo de comércio pode ser encarado como a atuação do estabelecimento, enquanto organização, para alcançar o escopo de lucro. Este tem por causa a eficiência da organização e em estreita relação com a combinação produtiva dos diversos fatores. ${ }^{86}$

Esta combinação (ordenação do estabelecimento) é determinada na agricultura por uma série de escolhas que têm por objeto o fundo; tais são as escolhas concernentes às combinações de culturas, às espécies cultivadas, ao revezamento destas, à distribuição da superfície entre as diversas culturas, aos sistemas de transformação dos produtos não-vendidos imediatamente, às atividades manufatureiras ou de transformação, à escolha dos contratos com o proprietário fundiário e mão-de-obra, à escolha dos modos de execução das obras rurais e à escolha dos modos de fertilização do terreno, etc.

A caracterização do estabelecimento agrário resulta do complexo das seguintes escolhas econômicas: da potencialidade da produção, da qualidade do produto e, indiretamente, da facilidade no escoamento da mercadoria. Em resumo, o escopo de lucro. ${ }^{87}$

Sucede que ao se aplicarem as qualidades pessoais do empresário, estas objetivam certos fatores duradouros do estabelecimento, tais como o nível de produção unitária, a qualidade do produto, a energia dos empregados, etc.

Exemplificando com um estabelecimento voltado para o cultivo, é possível a substituição de um titular por outro sem se configurarem repercussões

86 Id., Ibid., p. 83 .

87 Id., Ibid., p.83. 
apreciáveis. Daí decorrer a transferebilidade sempre mais plena do estabelecimento e de seu fundo de comércio. ${ }^{88}$

Não se deve desprezar um outro aspecto da fisionomia do fundo de comércio. O processo opera principal, embora não exclusivamente, através da valorização das qualidades naturais do fundo, o que contribui para exaltar as peculiaridades da produção. E isto nos interessa sob o aspecto da tutela do fundo de comércio. $^{89}$

Pode ocorrer que a proibição de concorrência por ocasião da transferência de estabelecimentos agrários contraste com o direito comunitário europeu. Isto sucederá quando o pacto contendo proibição de concorrência não tenha sido estipulado com o fim de assegurar o que não se poderia ter realizado de outra forma ao cessionário a exploração comercial dos conhecimentos tecnológicos cedidos. $^{90}$

É manifesto que o setor agrário dificilmente poderia estar interessado em uma tal decisão, todavia, a hipótese não seria completamente impossível (pensemos na cessão de estabelecimento agrícola que vende fruta em invólucros idealizados pelo cedente, que precisou construir maquinária especial). A incompletude e atraso do enfoque em matéria de concorrência na agricultura: pensemos no caso de um empresário agrário que tenha criado uma nova variedade de uvas que fornecem vinho de sabor particularíssimo e apreciado ou produto de mesa especial; no caso a concorrência do cedente poder-se-ia realizar não tanto ao desviar clientela, produzindo vinho ou cachos de uva iguais, mas vendendo videiras ou transferindo - por formas diversas, mas substancialmente equivalente a técnica do enxerto, operando, pois, numa fase diferente das tipificadas como atividades conexas. $^{91}$

Em festejada monografia Luís de Lima Stefanini, após indicar o art. $4^{\circ}$, n. VI do Estatuto da Terra e o art. $6^{\circ}$, n. III, e 25 do Decreto n. 55.891, de 31 de março de 1965, conclui que: "este mesmo decreto regulamentador, mais abaixo, em

88 Id., Ibid., p.83.

89 Id., Ibid., p. 83

90 Costato, Luigi, op. cit. p. 181

91 ld., Ibid., p.182. 
seu art. 25, confunde ainda mais a noção de empresa rural aproximando a acepção de empresa da noção de estabelecimento agrário... Ora, uma classificação tem que ser afeta ao primado conceituativo da coisa - no caso, a empresa rural. Através dessa classificação, compreende-se filiada a idéia de empresa rural à estabelecimento agrário... Afinal, poder-se-ia perguntar: o que é empresa rural? O empreendimento explorativo (noção da Lei $n$. 4.504, de 1964), ou imóvel rural, objeto desta exploração? Certo é que a empresa rural não pode ser as duas coisas ao mesmo tempo; tampouco ser a unificação destas duas idéias, pois cada uma é integrante de noções heterogêneas. ""22

A matéria não é versada entre nós. Justifica-se porque o estudo da empresa agrária não tem sido desenvolvido na bibliografia nacional e quanto ao estabelecimento, por conseqüência, permanece esquecido de análise. Daí permanecer a confusão acima detectada na legislação. 